\title{
Peran Koperasi Unit Desa Dalam Kegiatan Usaha Masyarakat
}

\author{
Donald Samuel Slamet Santosa; Ida Yuliana Putri \\ Program Studi Pendidikan Ekonomi, FKIP, Universitas Kristen Satya Wacana \\ J1. Diponegoro 52-60 Salatiga \\ Email: donald.samuel@staff.uksw.edu
}

\begin{abstract}
Abstrak
Koperasi merupakan salah satu bentuk solusi pemberdayaan masyarakat karena adanya semboyan atau tujuan untuk menyejahterakan anggota. Sebagai badan usaha yang dimiliki oleh anggota, berbagai keuntungan dan manfaat yang diperoleh oleh koperasi dapat dinikmati pula oleh para anggota. Penelitian ini bertujuan untuk menganalisis peran Koperasi Unit Desa (KUD) dalam menunjang kegiatan usaha masyarakat. Penelitian ini menggunakan metode penelitian kualitatif. Data dikumpulkan melalui wawancara semi terstruktur dan FGD, yang kemudian divalidasi melalui triangulasi sumber dan teknik. Data dianalisis dengan menggunakan teknik analisis interaktif model Miles dan Huberman. Hasil penelitian menunjukkan terdapat 2 peran KUD, yaitu peran langsung dan peran tidak langsung. Peran langsung meliputi: 1) kegiatan perkreditan; 2) penyedia dan penyaluran sarana produksi; 3) pengolahan dan pemasaran hasil produksi; 4) pengangkutan dan perdagangan. Sedangkan peran tidak langsung meliputi: 1) membangun dan mengembangkan potensi dan kemampuan ekonomi anggota; 2) meningkatkan kesejahteraan ekonomi dan sosial; 3) mempertinggi kualitas kehidupan; 4) mengurangi pengangguran dan kemiskinan; 5) mengurangi urbanisasi.
\end{abstract}

Kata Kunci: Peran KUD, kegiatan usaha

\begin{abstract}
Co-operation is one of solution in society development, because of its motto or goals: member's wealth. As the organization that members-owner, many provits and benefits that achieved by cooperation may used by co-operation's members. This research aim to analyzed the role of village unit co-operation in support sociecty's business. This research is qualitative research . Data collected by semi structured interview and Focus Group Discussion, that validated by sources and technique triangulation. Data analyzed by interactive analysis model of Miles and Huberman. Results of this research is 2 main roles: direct role and indirect role. The direct role consist by: 1) kredit activity; 2) advisor and distributor of production equipment; 3) processing and marketing of product; 4) distributing and trading. Then, indirect roles consist by: 1) developing member potency and economic ability; 2) improving economic wealth and social; 3) improving living quality; 4) reducing unemployment and poverty; 5) reducing urbanization.
\end{abstract}

Keywords: Role Village Unit Co-operation, Business

\section{A. Latar Belakang}


Menurut Undang-Undang RI No. 25 Tahun 1992 tentang perkoperasian menyebutkan bahwa koperasi adalah badan usaha yang beranggotakan orang-seorang atau badan hukum koperasi dengan melandaskan kegiatannya berdasarkan prinsip koperasi sekaligus sebagai gerakan ekonomi rakyat yang berdasarkan atas asas kekeluargaan. Berdasarkan definisi tersebut, dapat dijelaskan bahwa koperasi terdiri dari para anggota yang tergabung dalam sebuah keluarga, dan perlu bergerak untuk menyejahterakan para anggotanya (sesuai dengan prinsip koperasi).

Dari berbagai jenis koperasi, Koperasi Unit Desa (KUD) merupakan koperasi yang secara langsung berhubungan dengan usaha yang dilakukan oleh masyarakat di desa. Keberadaan KUD mempunyai peranan yang sangat penting didalam suatu daerah untuk memenuhi kebutuhan masyarakat serta memenuhi perekonomian masyarakat. Peran koperasi seharusnya sebagai pusat pelayanan dalam mengembangkan usaha masyarakat di daerah tersebut, serta memberi bantuan kepada masyarakat desa untuk mengembangkan usaha yang mereka jalankan baik dari segi peminjaman modal, produksi dan pemasaran.

Meski memiliki peran yang penting, namun kenyataan yang ditemui di lapangan menunjukkan hal yang berbeda. Kenyataan ini ditemukan di Desa Tegowanuh, Kecamatan Kaloran, Kabupaten Temanggung, Jawa Tengah. Kebanyakan masyarakat setempat berprofesi sebagai pengrajin genteng. Terdapat sebuah KUD di desa tersebut, yaitu KUD Sinar Cemerlang. Berdasarkan pengamatan yang dilakukan, KUD Sinar Cemerlang kurang dalam memaksimalkan perannya sebagai penyedia dan peyaluran sarana produksi, pengolahan dan pemasaran hasil produksi serta perdagangan dan pengangkutan yang nantinya berdampak pada kesuksesan wirausaha pengrajin genteng di desa Tegowanuh.

Masalah yang tampak adalah masalah yang terkait dengan peranan KUD dan kurangnya kesadaran masyarakat tentang arti penting KUD. Peranan koperasi yang rendah berdampak pada kesehatan koperasi dan juga kesuksesan para pengrajin genteng. Berikut beberapa fenomena problematis yang berhasil dihimpun dalam pengamatan pendahuluan.

1. Keberadaan KUD Sinar Cemerlang masih belum digunakan sepenuhnya untuk mengembangkan usaha kerajinan genteng masyarakat.

2. Banyak warga yang mengembangkan usaha kerajinan genteng tanpa meminjam dana dari KUD. Mereka memilih badan usaha lain untuk melakukan peminjaman dana.

3. Tidak adanya sosialisasi dari pengurus koperasi untuk masyarakat agar menggunakan jasa koperasi. 
4. Koperasi belum mengadakan jasa penyaluran sarana produksi.

5. Bunga yang ada di koperasi belum termasuk kategori murah untuk ukuran masyarakat desa setempat.

Bertolak dari permasalahan tersebut, maka sangat strategis apabila dikaji lebih lanjut mengenai peran KUD dalam menunjang kegiatan usaha masyarakat. Supaya kajian menjadi ilmiah, maka kajian ini dilakukan dalam bentuk penelitian.

\section{B. Kajian Teoretis}

Bahasan mengenai peran koperasi tidak dapat terlepas dari aturan hukum yang mendasari, dan teori-teori yang terkait. Koperasi sebagai badan usaha yang berasaskan kekeluargaan di dasari atas berbagai fungsi dan peran. Berdasarkan pasal 4 Undang-Undang Nomor 25 Tahun 1992 tentang Perkoperasian adalah sebagai berikut:

1. Membangun dan mengembangkan potensi dan kemampuan ekonomi anggota pada khususnya dan masyarakat pada umumnya untuk meningkatkan kesejahteraan ekonomi dan sosialnya;

2. Mempertinggi kualitas kehidupan manusia dan masyarakat;

3. Memperkokoh perekonomian rakyat sebagai dasar kekuatan dan ketahanan perekonomian nasional dengan koperasi sebagai sokogurunya;

4. Mewujudkan dan berusaha untuk mengembangkan perekonomian nasional yang merupakan usaha bersama berdasar atas asas kekeluargaan dan demokrasi ekonomi.

Apabila dianalisis lebih lanjut, keempat peran koperasi tersebut merupakan dampak yang diperoleh oleh anggota atau masyarakat umum akibat adanya koperasi. Dengan demikian, peran koperasi akan dirasakan oleh berbagai kalangan, yang tidak hanya terbatas pada anggota saja, namun juga masyarakat secara umum.

Selain peran koperasi menurut UU, Anoraga dan Widiyanti (2003:24) dan Deliarnov (2007:28) juga memberikan penjabaran mengenai peran koperasi. Kali ini, koperasi yang dimaksud lebih difokuskan pada Koperasi Unit Desa. Secara garis besar, peran KUD menurut Anoraga dan Widiyanti yaitu sebagai pusat pelayanan-pelayanan didaerah pedesaan. Sedangkan secara rinci, berdasarkan sintesis terhadap kedua sumber, KUD memiliki peran sebagai berikut.

1. Perkreditan. KUD mempunyai peran untuk keperluan produksi dan penyedia kebutuhan, modal investasi dan modal kerja atau usaha bagi anggota KUD dan warga desa umumnya. 
Serta untuk keperluan dalam kesuksesan usaha. Perkreditan modal dilakukan dengan kaitannya usaha simpan pinjam dana bagi anggota maupun masyarakat.

2. Penyedia dan penyaluran sarana-sarana produksi, dalam hal ini KUD sebagai penyedia yaitu menyediakan sarana produksi sebelum dan sesudah panen, sarana untuk keperluan industri/kerajinan seperti barang mentah untuk keperluan kerajinan dan penyedia barangbarang keperluan sehari-hari khususnya bahan pokok dan jasa-jasa lainya. Penyaluran sarana-sarana produksi, KUD diharapkan dapat menjadi agen untuk mencari bahan pokok barang produksi supaya bahan yang dibutuhkan harga lebih murah.

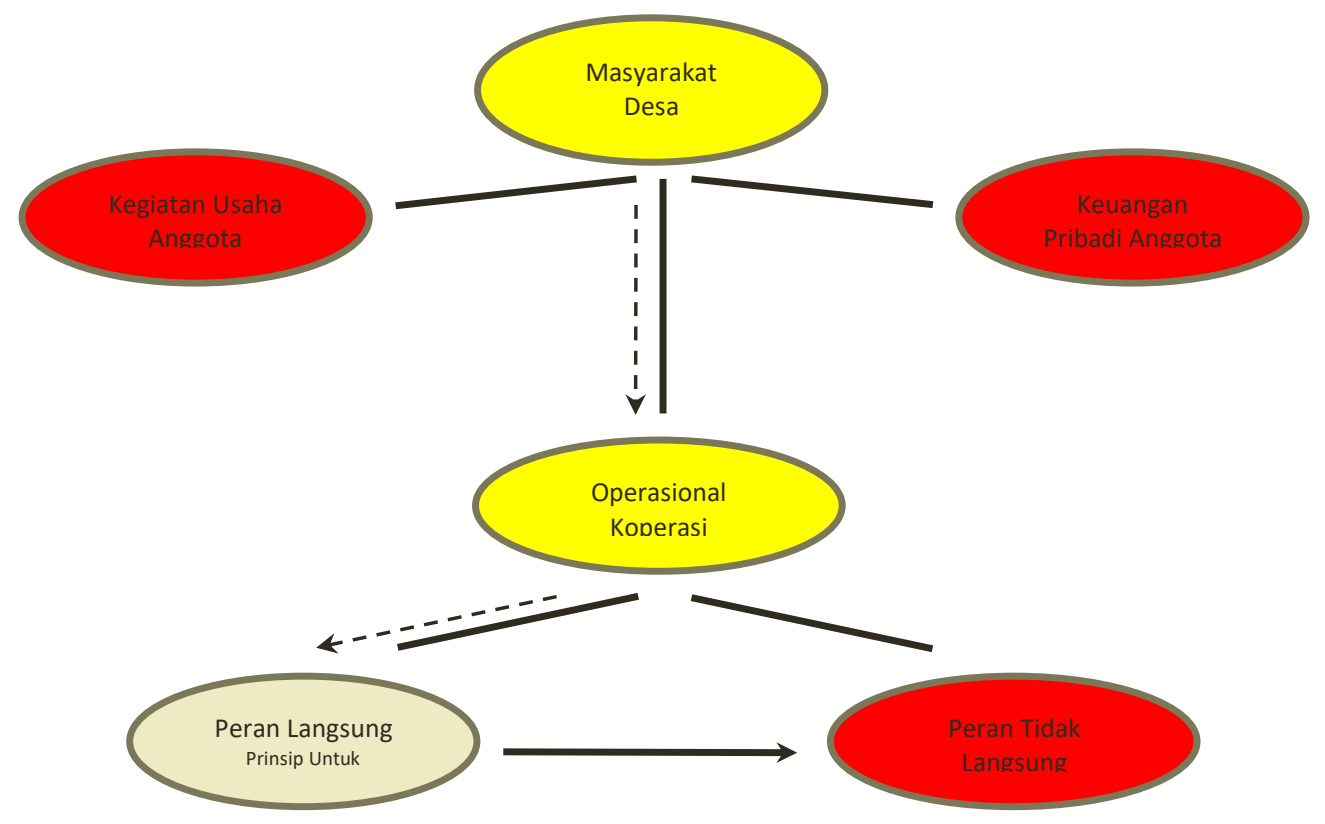

Gambar Kerangka Berpikir Penelitian

3. Pengolahan dan pemasaran hasil produksi/industri dari para anggota KUD dan warga desa umumnya. Pengolahan yaitu KUD mampu memproduksi unit kerajinan sendiri di dalam KUD tersebut di mana KUD menggerakkan SDM untuk dibina sehingga menghasilkan produk yang lebih berkualitas. Sedangkan penyaluran yaitu KUD mampu melakukan penyaluran penjualan hasil produksi bagi KUD sendiri anggota maupun masyarakat. Penyaluran hasil produksi dilakukan agar masyarakat lebih mudah dalam menjual hasil produksinya. 
4. Kegiatan perekonomian lainya seperti perdagangan, pengangkutan dan sebagainya. KUD menyediakan sarana bagi anggota, masyarakat untuk kegiatan perdagangan dan pengangkutan. bukan hanya perdagangan untuk barang kerajinan akan tetapi perdagangan untuk kebutuhan pokok masyarakat maupun pengangkutan barang produksi.

Berdasarkan penjelasan dari Anoraga dan Widayanti; dan Deliarnov tersebut, tampak bahwa peran yang dijelaskan lebih pada peran secara langsung yang mengarah pada kegiatan usaha yang dilakukan oleh para anggota. Hal ini tentu berbeda dengan peran yang telah dijelaskan oleh UU No. 25, yang lebih berfokus pada peran secara tidak langsung.

\section{Metode Penelitian}

Penelitian ini menggunakan metode penelitian kualitatif karena permasalahan yang kompleks, dinamis, dan penuh makna yang terjadi. Tempat dalam penelitian ini adalah KUD Sinar Cemerlang yang ada di Desa Tegowanuh, Kecamatan Kaloran, Kabupaten Temanggung, Jawa Tengah. Instrumen utama dalam penelitian ini adalah penulis sendiri. Penulis sebagai instrumen utama harus memahami metode penelitian kualitatif, mempunyai wawasan yang luas tentang bidang yang akan diteliti sehingga menuntut adanya pemahaman yang luas dan mendalam. Penulis juga akan menggunakan beberapa alat bantu dalam mengumpulkan data, salah satunya adalah pedoman wawancara. Pedoman wawancara digunakan untuk acuan mengarahkan pewawancara dalam memperoleh data yang dibutuhkan melelui wawancara semi tersetruktur (Moleong, 2010). Selain wawancara semi terstruktur penulis juga menggunakan teknik pengumpulan data menggunakan dokumentasi untuk menjaga agar data yang diperoleh terjamin validitasnya. Trianggulasi dalam penelitian ini menggunakan trianggulasi sumber.

Sebagai penelitian kualitatif, penelitian ini perlu memiliki satuan analisis dan satuan pengamatan. Satuan analisis dalam penelitian ini adalah peran KUD. Sedangkan satuan pengamatan dalam penelitian ini adalah KUD Sinar Cemerlang yang didalamnya memuat pengurus, ketua dan anggota KUD Sinar Cemerlang sekaligus wirausaha pengrajin genteng.

Penelitian ini menggunakan data primer, sehingga dalam pengumpulan data peneliti menggunakan sumber primer. Data primer diperoleh dari pengurus, ketua dan anggota KUD Sinar Cemerlang yang ditarik secara purposive sampling dan dilanjutkan dengan snowball sampling. Sumber data penelitian ini adalah pihak-pihak yang dinilai oleh penulis mempunyai pengetahuan dan informasi tentang hal-hal yang dibutuhkan dalam penelitian. Pihak-pihak ini 
disebut informan. Penulis mengobservasi pasif tentang peran KUD Sinar Cemerlang dalam kegiatan usaha masyarakat pengrajin genteng.

Teknik analisis data yang digunakan dalam penelitian ini adalah analisis interaktif model Miles and Huberman. Sugiyono (2010:337) menjelaskan bahwa "Aktivitas dalam analisis data kualitatif dilakukan secara interaktif dan berlangsung secara terus menerus sampai tuntas, sehingga datanya sudah jenuh. Aktivitas dalam analisis data meliputi, data reduction, data display, data conclusion drawing/verification". Setelah peneliti melakukan pengumpulan data, maka peneliti perlu melakukan anticipatory sebelum melakukan reduksi data. Setelah data direduksi, langkah selanjutnya adalah mendisplaykan data. Penyajian akan disajikan oleh peneliti dalam bentuk uraian singkat. Langkah terakhir dalam teknik ini adalah penarikan kesimpulan dan verifikasi.

\section{Hasil Penelitian dan Pembahasan}

Sesuai dengan permasalahan penelitian yang telah diungkapkan sebelumnya, hasil penelitian ini juga menunjukkan bahwa KUD Sinar Cemerlang belum menjalankan perannya dengan baik. Meski demikian, hasil wawancara dan FGD menunjukkan bahwa anggota maupun pengurus koperasi merasakan manfaat dari koperasi, khususnya yang berhubungan dengan usaha-usaha koperasi dalam memenuhi kebutuhan masyarakat dan berpengaruh positif terhadap perubahan kehidupan masyarakat. Selain itu, anggota dan pengurus juga memiliki idealisme dan berharap koperasi dapat menjalankan perannya. Untuk itulah wawancara dilakukan secara mendalam untuk menjaring apa saja yang menjadi kebutuhan anggota atau ekspektasinya terhadap peran koperasi.

Pengumpulan data dan analisis yang telah dilakukan menunjukkan bahwa semua peran dalam unsur teoretis terkonfirmasi dalam pengumpulan data penelitian ini. Adanya peran secara langsung dan peran secara tidak langsung dalam teori juga ditemukan dalam penelitian ini. Meski demikian, konsep yang diangkat dalam ranah empirik tersebut belum tentu memiliki kesamaan yang persis dengan peran secara teoretik. Adanya kesamaan atau kemiripan antara teori dengan temuan menjadi dasar bagi proses konfirmasi.

Temuan baru yang diperoleh adalah adanya berbagai data yang tidak dapat terkonfirmasi ke peran manapun. Hal inilah yang kemudian didalami, diangkat menjadi satu konsep baru, dan menjadi tambahan atau pelengkap bagi peran yang sudah ada secara teoretis. 
Beberapa peran yang diberikan koperasi terhadap masyarakat dan harapan terhadap peran, yang sejauh ini tidak ditemukan dalam teori adalah sebagai berikut.

1. Mengurangi pengangguran dan kemiskinan. Pengangguran merupakan kondisi di mana seseorang tidak mendapatkan kesempatan kerja untuk memperbaiki hidupnya. Dampak utama dari pengangguran adalah kemiskinan, kemiskinan merupakan masalah yang sangat umum jika seseorang tidak mampu menggali ketrampilan yang ada (Daulay, 2009). Kemiskinan merupakan kondisi seseorang dengan sumber daya (material, sosial dan budaya) yang sangat terbatas (Khomsan, 2015:2). Menurut pengertian tersebut sumber daya yang menyebabkan kemiskinan meliputi material, sosial, dan budaya.

2. Mengurangi Urbanisasi. Rendahnya tingkat urbanisasi merupakan peran yang nyata di mana koperasi telah memberikan jasanya terhadap pembangunan ekonomi. Kegiatan usaha koperasi yang dilakukan memberikan banyaknya kesempatan kerja karena masyarakat terdorong untuk menggunakan jasa koperasi sebagai jalan untuk meningkatkan keterampilannya. Menurut Prawiro (1983:106), urbanisasi merupakan suatu perpindahan kebudayaan atau pandangan hidup dan tingkah laku.

Hal seperti inilah yang selama ini belum dibahas dalam teori mengenai peran koperasi seperti dikemukakan oleh Anoraga dan Widiyanti, pasal 4 UU No 25 Tahun 1992, serta Deliarnov. Bahwa peran koperasi bukan hanya sebagai perkreditan, penyedia dan penyaluran sarana produksi, pengolahan dan pemasaran hasil produksi, perdagangan dan pengangkutan. Akan tetapi setelah dilakukan penelitian di KUD Sinar Cemerlang terdapat peran koperasi yang secara tidak langsung mempengaruhi anggota maupun masyarakat. Untuk itu, ke depan perlu diungkapkan bahwa salah satu peran KUD secara tidak langsung adalah mengurangi pengangguran, kemiskinan dan mengurangi tingkat urbanisasi.

Berdasarkan temuan baru tersebut, maka peran Koperasi Unit Desa tetap dapat dikelompokkan ke dalam 2 kelompok, namun dengan isi yang berbeda sebagai berikut.

1. Peran secara langsung. Peran KUD secara langsung terkait dengan beberapa hal sesuai dengan peran yang telah dikemukakan secara teori bahwa KUD memiliki peran:

a. Perkreditan, untuk keperluan produksi dan penyedia kebutuhan modal investasi dan modal kerja /usaha bagi anggota KUD dan warga desa umumnya.

b. Penyedia dan penyaluran sarana-sarana produksi, seperti sarana sebelum dan sesudah panen, sarana untuk keperluan industri/kerajinan dan sebagainya, penyedia dan 
penyaluran barang-barang keperluan sehari-hari khususnya bahan pokok dan jasa-jasa lainya.

c. Pengolahan dan pemasaran hasil produksi/industri dari para anggota KUD dan warga desa umumnya.

d. Kegiatan perekonomian lainya seperti perdagangan, pengangkutan dan sebagainya.

2. Peran koperasi secara tidak langsung berdasarkan hasil analisis dan pembahasan yang telah dilakukan adalah sebagai berikut:

a. Membangun dan mengembangkan potensi dan kemampuan ekonomi anggota pada khususnya dan masyarakat pada umumnya;

b. Meningkatkan kesejahteraan ekonomi dan sosialnya;

c. Mempertinggi kualitas kehidupan manusia dan masyarakat;

d. Memperkokoh perekonomian rakyat sebagai dasar kekuatan dan ketahanan perekonomian nasional dengan koperasi sebagai sokogurunya.

e. Mewujudkan dan berusaha untuk mengembangkan perekonomian nasional yang merupakan usaha bersama berdasar atas asas kekeluargaan dan demokrasi ekonomi.

f. Mengurangi pengangguran dan kemiskinan.

g. Mengurangi urbanisasi.

Ketujuh peran tidak langsung tersebut dapat disederhanakan kembali, mengingat peran keempat dan kelima cenderung bersifat idealis-filosofis, dan sebenarnya sudah menjadi bagian dari peran tidak langsung yang lain. Dengan demikian, peran tidak langsung yang ada ditetapkan ulang menjadi hanya 5 peran, tanpa adanya peran keempat dan kelima.

Pelaksanaan peran koperasi diharapkan dan dipercaya oleh anggota dapat berdampak positif bagi masyarakat (Nasution, 2008). Dengan adanya peran langsung dan tidak langsung tersebut, maka keberadaan KUD Sinar Cemerlang berpotensi membawa dampak positif baik bagi anggota, pengrajin, masyarakat.

Dari sisi anggota dapat melayani pembiayaan dalam mengembangkan usahanya, meningkatkan kesejahteraan bagi para anggota, memberikan ketenangan dan pemenuhan kebutuhan bagi para anggota, mengembangkan usaha dan meningkatkan pendapatan para anggota dan pengrajin genteng. Pemberian rasa kesejahteraan bagi anggota sangat berarti dan bermanfaat bagi anggota koperasi dimana menciptakan hubungan yang positif antara anggota dan koperasi. 
Dari sisi pengrajin selain mendapat pelayanan pembiayaan juga mendapat pembinaan atau pelatihan sehubungan dengan peningkatan kualitas, bagi masyarakat yang semula tergantung kepada pengumpul genteng sekarang mulai menggunakan jasa koperasi sebagai usaha simpan pinjam, memotivasi tingkat kerja pengrajin agar lebih berkualitas. Selain itu masyarakat juga memiliki kualitas diri untuk meningkatkan ketrampilan dan kemampuan SDM mereka, meningkatkan pendapatan ekonomi pengrajin genteng.

Untuk itulah perlu disusun strategi optimalisasi pengelolaan KUD guna meningkatkan perannya bagi para anggota. Kaitannya dengan hal ini, pihak utama yang perlu ditingkatkan kinerjanya adalah pengurus KUD (Mutis, 2004). Apabila diperhatikan lebih lanjut, pengurus KUD Sinar Cemerlang adalah masyarakat desa setempat yang cenderung berpendidikan rendah dan kurang memiliki bekal yang cukup untuk bekerja. Untuk itulah, maka pimpinan KUD perlu menerapkan gaya kepemimpinan transaksional (Rezeki, 2017). Pimpinan perlu mengarahkan pengurus KUD untuk dapat belajar secara terarah, yang salah satunya melalui belajar yang berbasis penelitian (Santosa dan Togatorop, 2017). Belajar berbasis penelitian merupakan salah satu strategi belajar yang dapat diterapkan, di mana pengurus koperasi melakukan penelitian-penelitian kecil atau sederhana guna mendapatkan ilmu atau pembelajaran tertentu yang dapat berdampak pada kemajuan koperasi.

\section{E. Simpulan dan Saran}

Berdasarkan hasil penelitian yang telah dibahas, dan sesuai dengan tujuan penelitian yang telah ditetapkan, maka dapat ditarik simpulan berikut:

Peran KUD dalam menunjang kegiatan usaha masyarakat meliputi peran secara langsung dan tidak langsung. Peran langsung terdiri dari: 1) kegiatan perkreditan; 2) penyedia dan penyaluran sarana produksi; 3) pengolahan dan pemasaran hasil produksi; 4) pengangkutan dan perdagangan. Sedangkan peran tidak langsung meliputi: 1) membangun dan mengembangkan potensi dan kemampuan ekonomi anggota; 2) meningkatkan kesejahteraan ekonomi dan sosial; 3) mempertinggi kualitas kehidupan; 4) mengurangi pengangguran dan kemiskinan; 5) mengurangi urbanisasi.

Berdasarkan simpulan penelitian tersebut, dapat diberikan saran-saran bagi pihak-pihak yang terkait dengan penelitian ini. Adapun saran dari penelitian ini adalah sebagai berikut. 
1. Bagi pengurus KUD Sinar Cemerlang. Disarankan supaya melaksanakan peran yang lain yang belum bisa dilaksanakan, dan melaksanakan peran yang sudah terlaksana dengan cara yang lebih baik. Pimpinan KUD perlu menerapkan gaya kepemimpinan transaksional dalam memimpin pengurus koperasi. Selain itu, pengurus koperasi juga diharapkan untuk melakukan pembelajaran dengan cara melakukan penelitian-penelitian secara sederhana (pembelajaran berbasis penelitian).

2. Bagi Masyarakat Pengrajin. Disarankan para pengrajin lebih memanfaatkan jasa koperasi dan lebih meningkatkan kualitas produksi barang yang dipasarkan. Supaya barang produksinya lebih dikenal masyarakat lebih luas bukan hanya wilayah Jawa Tengah.

3. Bagi Peneliti Selanjutnya. Penelitian ini diharapkan sebagai bahan pertimbangan penelitian selanjutnya yang berhubungan dengan peran koperasi dalam kegiatan usaha masyarakat.

\section{Daftar Pustaka}

Anoraga, P., Widiyanti, N. 2003. Dinamika Koperasi. Jakarta: Rineka Cipta.

Deliarnov, B. 2007. Ilmu Pengetahuan Sosial Ekonomi. Jakarta: Erlangga

Daulay, M. 2009. Kemiskinan Pedesaan, Medan: USU Press..

Khomsan, A. 2015. Indikator Kemisikinan dan Misklasifikasi Orang Miskin. Jakarta: Yayasan Pustaka Obor Indonesia.

Moleong, L. J. 2010. Metodologi Penelitian Kualitatif. Bandung: Remaja Rosdakarya.

Mutis, T. 2004. Pengembangan Koperasi. Jakarta: PT Grasindo.

Nasution, M. 2008. Koperasi Menjawab Kondisi Ekonomi Nasional. Jakarta Selatan: PIP \& LPEK.

Prawiro, R. H. 1983. Kependudukan, Teori, Fakta dan Masalah. Bandung: Alumni.

Rezeki, F. Pengembangan Model Pendidikan dan Pelatihan Gaya Kepemimpinan Transaksional Bagi Pengusaha Toko Kelontong. Jurnal Ecodunamika. 1 (2) 2017

Santosa, D. S. S., Togatorop, M. Evaluasi Metodologis Pembelajaran Berbasis Penelitian. Prosiding Seminar Pendidikan Ekonomi dan Bisnis. 3 (1) 2017.

Sugiyono. 2010. Memahami Penelitian Kualitatif. Bandung: Alfabeta.

Undang-Undang RI. No. 25 Tahun 1992 Tentang Perkoperasian 
